Stellenbosch Theological Journal 2021, Vol 7, No 1, 1-22

DOI: http://dx.doi.org/10.17570/stj.2021.v7n1.a08

Online ISSN 2226-2385 | Print ISSN 0028-2006

2021 (c) Pieter de Waal Neethling Trust

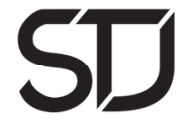

\title{
Exploring Exodus themes in the book of Amos
}

\author{
SD (Fanie) Snyman \\ University of the Free State \\ Bloemfontein, South Africa \\ snymansd@ufs.ac.za
}

\begin{abstract}
There is little doubt that the exodus event is regarded as a most important turning point for Israel's understanding of itself. The aim of this article is to investigate the occurrence of the Exodus tradition in the book of Amos. Once the occurrence of the exodus tradition has been determined the second aim is to establish the function of the exodus tradition in the book. This is done by providing the reader with cursory overview of the exodus event as it is told in Exodus 1-15, followed by a careful reading of the relevant texts taking the literary and historical dimensions of the texts in consideration. The investigation came to mainly three results: the exodus tradition is utilized in the book of Amos as a motivation for the prophecies of doom directed to Israel. Secondly, the exodus tradition is in fact turned against Israel and thirdly, the exodus event is radically relativized as an event not unique to Israel alone.
\end{abstract}

Keywords

Exodus tradition; Egypt; Book of Amos; plague; Cush

\section{Introduction}

There is little doubt that the Exodus event as recorded in Exodus 1-15 is foundational in the Old Testament/Hebrew Bible. Books on the theology of the Old Testament/Hebrew Bible confirm the importance of the exodus in the Old Testament/Hebrew Bible and for Israel's faith in YHWH. A quick survey of some books on Old Testament Theology confirm this consensus in scholarly circles:

- Von Rad (1975:176) regards the deliverance from Egypt as “Israel's original confession". 
- Zimmerli (1978:25) speaks of the Exodus event as a "fundamental confessional statement for the faith attested by the Old Testament".

- In many ways the narrative of Exodus 1-15 may be considered "the birth story of Israel as a people", says Birch (1999:99).

- For Rendtorff (2005:47) the Exodus "is the determinative event in Israel's history, for all times to come". Right at the beginning of the exodus narrative, for the first time ever, the children of Israel are now

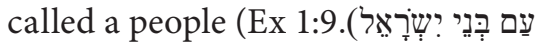

- For Waltke (2007:390) the signal act of deliverance in the Old Testament is Israel's exodus from Egypt.

- Jeremias (2015:89) noted that for Israel the deliverance from Egypt that culminated in the events at the Reed Sea in Exodus 14-15 was nothing else but the "Grunderfahrung der Fürsorge Gottes für sein Volk". Later experiences of God's redemptive acts only serve as the confirmation of this first experience.

It would be hard to overstate the central importance of the Exodus experience for Israel's understanding of itself and of its faith. Brueggemann (1997:179) stated that the Exodus became paradigmatic for Israel's testimony about Yahweh and it became an interpretative lens to guide, inform and discipline Israel's utterances about many aspects of its life. It is then no surprise that the exodus event reverberates through many parts of the Old Testament/Hebrew Bible. Von Rad (1975:176) stated in this regard that in the deliverance from Egypt Israel saw the guarantee for all the future, the absolute surety for YHWH's will to save, something like a warrant to which faith could appeal in times of trial. Hoffman (1989:169) noted that the Exodus is the most frequently mentioned event in the entire Old Testament.

The topic discussed in this contribution is to investigate the occurrence and function of the Exodus in the book of Amos. What is the function of the Exodus theme in the book of Amos? To answer this question, the main thrust of the Exodus narrative in Exodus 1-15 will first be determined and briefly summarized. Following on that, the central question put in this paper will be answered via a careful reading of the relevant texts taking the literary and historical contexts of the texts in consideration. 


\section{A brief overview of the Exodus event as recorded in Exodus 1-15}

The Exodus continues the story of Joseph (Gen 37-50) who arrived in Egypt as a result of his brothers' conspiracy to get rid of him. The Israelites living in Egypt became a threat to a new pharaoh because they "were fruitful and multiplied greatly and became exceedingly numerous" (Ex 1:6). The pharaoh decided to put them to forced labour in an effort to control their numbers. In another more extreme effort the pharaoh issued an order that every Israelite boy that is born should be thrown in the river Nile (Ex 1:22). YHWH heard and saw the terrible plight of his people (Ex 2:24-25) and decided to do something about this dire situation. He revealed himself to Moses as YHWH, the God of Abraham, Jacob and Isaac and commissioned Moses "to bring my people the Israelites out of Egypt" (Ex 3:10). Eventually Moses, with the assistance of his brother Aaron, confronted the king of Egypt in a series of meetings where the king together with his people had to suffer "signs and wonders" (Ex 7:3). Zimmerli (1978:22) remarked in this regard "that there is no other event in the entire history of Israel so surrounded by a plethora of miraculous interventions on the part of $\mathrm{YHWH}$ as the event of the deliverance from Egypt". The last wonder was the death of the Egyptian firstborn including the firstborn of the pharaoh himself. As a result of this he summoned Moses and Aaron to allow the people of Israel to go and worship YHWH (Ex 12:31) as they initially requested. The tenth wonder is closely linked with the Passover festival celebrating the fact the fact that YHWH "passes over" the Israelites and did not strike down the firstborn of the Israelites due to the blood smeared unto the sides and tops of the doorframes of the houses where ate the lamb slaughtered (Ex 12). The Exodus narrative culminated in the passing of the Israelites through the Reed Sea while the Egyptian military forces were defeated by YHWH who swept them into the sea so that no one of the entire army of Egypt survived (Ex 14:27-28). This saving event was summarized in a victory song in Exodus 15. Miriam, the sister of Moses and Aaron sang a song: "Sing to the Lord, for he is highly exalted. The horse and its rider he cast into the sea" (Ex 15:21). God has led his people out of Egypt "and can derive from this the hope of helping, saving, and forgiving action in the future" (Rendtorff 2005:47). 


\section{References to Egypt in the book of Amos}

According to Brueggemann (1997:177) Israel once they began telling their history, "retold all of its experience through the powerful, definitional lens of the Exodus memory". The formulation used by Brueggemann is significant. It does not suggest that the Exodus memory was initially a written record of events. It rather reflects an initial oral tradition - a position that is adopted in this paper as well. This is no different in the book of the Twelve where the Exodus event is frequently referred to especially in the book of Hosea (Hos 2:17; 7:11; 7:16; 8:13; 9:3; 9:6; 11:1; 11:5; 11:11; $12: 2 ; 12: 10 ; 12: 14 ; 13: 4$ ), but also in other books (Joel 4:19; Micha 6:4; 7:15; Nah 3:9; Hag 2:5; Zech 10:10; 10:11; 14:18; 14:19). The book of Amos is no exception in this regard.

Broadly speaking, the book of Amos can be divided in four major parts. After an introduction (1:1-2) a series of prophecies directed at foreign nations and culminating in prophecies against Judah and Israel (1:3-2:16), followed then by another series of prophecies against Israel in Amos 3-6 and finally Amos 7-9 introduced by five visions. The following verses make explicit references to Egypt: Amos 2:10; 3:1; 3:9; 4:10; 8:8; 9:5; 9:7.

Two of these texts (Amos 8:8 and 9:5) cannot be related to the Exodusevent and will therefore be excluded from this investigation.

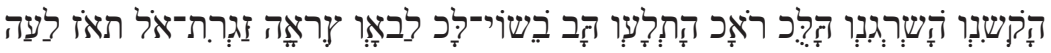

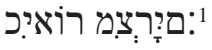

Shall not the land tremble on this account, and everyone mourns who dwells in it, and all of it rise like the Nile, and be tossed about and sink again, like the Nile of Egypt?"2

Amos 8:8 forms part of a pericope (Amos 8:4-14) where the prophet utters once again a prophecy of doom upon Israel because of social injustices prevailing in society. The judgement will be experienced in the form of an earthquake. The coming earthquake is compared to the seasonal rising and falling of the river Nile in Egypt.

1 Hebrew texts are quoted from Elliger, K \& Rudolph, W 1984. Biblia Hebraica Stuttgartensia. Stuttgart: Deutsche Bibelgesellschaft.

2 English texts are quoted from the Revised Standard Version (1971). 


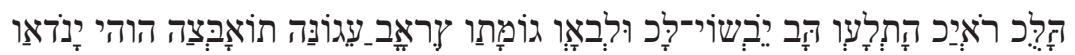

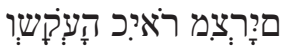

The Lord, GOD of hosts, he who touches the earth and it melts, and all who dwell in it mourn, and all of it rises like the Nile, and sinks again, like the Nile of Egypt.

Amos 9:5 is an almost verbatim repetition of Amos 8:8 and forms part of the third doxology in the book (Amos 4:13; 5:8-9). It alludes to an earthquake and likens the movement of the earth associated with an earthquake with the movement of the water of the river Nile in Egypt.

The mentioning of Egypt in both Amos 8:8 and 9:5 cannot be regarded as references to the Exodus tradition telling the event of Israel's deliverance from the hardships of Egypt to the freedom of their own land. In both verses eretz (ארץ) is used as an indication of the land where Israel as the people of God make a living. It is thus rather the tradition of the land or perhaps creation traditions at work here rather than the exodus tradition. Both these verses refer to a geographical phenomenon in the form of an earthquake that will occur. The ebb and flow of the river Nile in Egypt is used as an example to illustrate the point the author wishes to make.

\section{Exploring the function of the Exodus theme in the book of Amos}

Three different functions for making use of the Exodus theme in the book of Amos have been determined:

The Exodus as the motive for the prophecies directed at Israel Amos 2:10

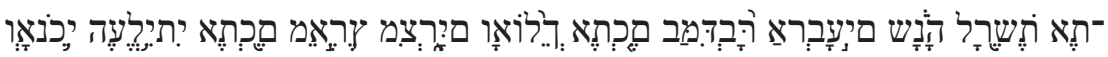

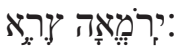

Also I brought you up out of the land of Egypt, and led you forty years in the wilderness, to possess the land of the Amorite.

Amos 2:10 is part of the first major section of the book consisting of six prophecies directed at foreign nations (Amos 1:3-2:3) followed by one directed at Judah (Amos 2:4-5) and culminating in a prophecy against 
Israel (Amos 2:6-16). In the first part of the prophecy (verses 6-8) directed to Israel YHWH speaks about Israel and her sins. The sins mentioned are sins committed to their fellow Israelites. All the sins mentioned are related to social injustices done to fellow Israelites.

In verses 9-11 YHWH's redemptive deeds in the history of the people are mentioned. Verse 9 mentioned the granting of the land and it was reiterated again in the second part of verse 10. YHWH also sent the people prophets and Nazirites to guide the people in the ways YHWH wanted them to follow. In verse $10 \mathrm{YHWH}$ addresses Israel changing to second person singular form ("I brought you up from Egypt") thereby addressing Israel directly (Eidevall 2017:117). What YHWH did to his people in the past is contrasted with the acts of the people now living in the land. YHWH's act in the Exodus event is in fact rejected by Israel (Hadjiev 2009:58). In this prophecy Israel is reminded of YHWH's acts of deliverance in the history of the people. YHWH brought (הלע) his people up out of the land of Egypt. It is interesting and important to note that this is the only verb used in the book of Amos to describe the deliverance from Egypt (Amos 3:1; 9:7). The same verb is used in Exodus 3:8, 17 to describe this saving act of YHWH. The verb suggests a geographical connotation: moving from a lower place to a higher mountainous one (Brueggemann 1997:176; Niehaus 1992:369; Van Leeuwen 1985:88). It indicates not only a movement from the land of Egypt to the promised land, but also from metaphorically speaking, a movement from a situation of slavery to one of freedom. YHWH exalted Israel from a condition where they were slaves in a foreign country to a promised land where they will no longer be slaves but could enjoy freedom. The people of Israel were brought out of the bondage of Egypt to live in the promised land. Israel is reminded that they were an oppressed people serving as slaves to a foreign nation (Amos 2:10) but now they have become the oppressors not of another foreign nation but of their very own people (Amos 2:6-9) in the land granted to them. Instead of remaining a group of slaves, it is YHWH who made Israel into a people by delivering them from Egypt (Rudolph 1971:146). Garrett (2003:66) notes that the Amorites were mentioned twice creating an "inclusion structure framed by reference to the expulsion of the Amorites. The implication is that Israel, too, could be expelled". In other words, just as the Amorites were once destroyed by 
YHWH to make room for his people to occupy and make a living in the promised land, the same may now happen to Israel (Amos 2:13-16).

Amos 3:1

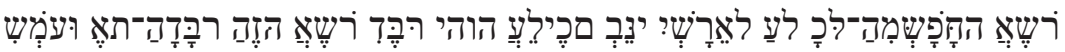

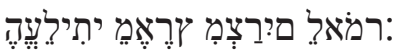

Hear this word that the Lord has spoken against you, O people of Israel, against the whole family which I brought up out of the land of Egypt.

Amos 3:1-2 introduces a new section in the book and can be seen as the introduction or prologue to the second part of the book (Amos 3-6). The

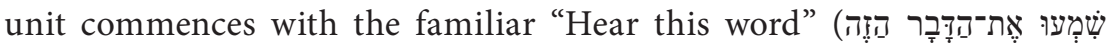
) that is also found in Amos 4:1 and 5:1. The people are called "children of Israel" and then it is further explicated as "the whole family" (or clan) indicating the close relationship the Israelites have with one another as well as the close relationship with YHWH (Eidevall 2017:123). In Amos 3:1 the people are reminded that YHWH brought them out of Egypt. The same verb (עלה) is once again used to describe the deliverance from Egypt. The fact that the deliverance from Egypt is repeated here serves as a link with the preceding unit $(2: 6-16)$. In this case YHWH's act of salvation is used as the motivation for the prophecies uttered and the punishment announced upon the people in this part of the book. The deliverance from Egypt was an act of YHWH's saving power, grace, and kindness to them (Paul 1991:101; Niehaus 1992:375). It is because YHWH rescued his people that they are addressed about their iniquities. As is the case in Amos 2:10, YHWH's acts in the past on behalf of his people stand in stark contrast to their current behaviour.

Amos 3:9

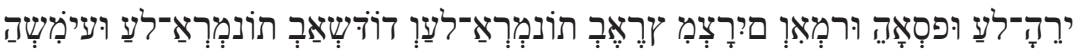

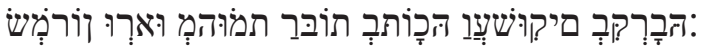

Proclaim to the strongholds in Assyria, and to the strongholds in the land of Egypt, and say, "Assemble yourselves upon the mountains of Samaria, and see the great tumults within her, and the oppressions in her midst." 
Amos 3:9 serves as the introduction to a prophetic oracle stretching to verse 15 proclaiming devastation to Israel because of their neglect in terms of social justice. In Amos 3:9 the land of Egypt is mentioned together with Ashdod known as a Philistine city. It seems odd to call upon a country (Egypt) and a city (Ashdod) with the city mentioned first to witness the unrest and oppression prevailing in Samaria as the capital of the Northern Kingdom. It is also the only instance in the Old Testament/Hebrew Bible where Egypt and Ashdod are mentioned together. It must also be noted that the land of Egypt is called upon but with no direct mentioning of the exodus from Egypt as was the case in Amos 2:10 and 3:1. The question to consider then is whether mentioning the land of Egypt in Amos 3:9 can be interpreted as a reference to the exodus tradition.

To answer this question, one has to briefly pay attention to the mentioning of Ashdod. It is interesting to note that the LXX has a different reading in this regard. The LXX reads "Assyria" instead of Ashdod probably because Assyria would serve as a better parallel to Egypt as a political power than Ashdod as a city-state of the Philistines. Although there is support for the reading of the LXX as the preferred reading (Barthélemy 1992:647), the reading of the MT has to be retained (Wolff 1977:189; Van Leeuwen 1985:124; Paul 1991:115-116; Eidevall 2017:130). To mention Ashdod is a subtle allusion to the land promise and the eventual granting of the land. In Joshua 11:22; 13:3 and 15:47 Ashdod is especially mentioned in connection with the conquest of the land. In Amos 3:9-15 the prophet announces the unthinkable possibility that Israel may lose the land they once occupied. In verse 11 it is said in no uncertain terms that "an adversary shall surround the land and strip you of your defence and your strongholds shall be plundered" (NRSV). The mentioning of Ashdod serves as a subtle reminder of the initial conquest of the land in stark contrast to the threat of losing the land.

Different answers were given to answer the question as to why Egypt was called upon as a witness "to see the great unrest within her and the oppression among her people" (Amos 3:9).

- Some scholars (Mays 1976:63; Van Leeuwen 1985:124) are of the opinion that Ashdod and Egypt were neighbouring states and therefore they are mentioned together. 
- Carroll (1992:193) thinks that the mentioning of Ashdod and Egypt has to do with an idea of some moral consensus with the implication that even these two (pagan) nations known for their acts of violence and injustice would be shocked by the conditions they are about to observe in Samaria.

- Other scholars (Rudolph 1971:163; Paul 1991:115) think that Ashdod and Egypt were summoned because of the stipulation in Israelite law that requires at least two witnesses in a lawsuit as proof of reliable evidence (Deut 17:6; 19:15).

- Another solution to the problem was to view the call to the entities as a rhetorical device rather than a historical indication (Rudolph 1971:163; Deissler 1981:105).

It has already been argued that in both Amos 2:10 and 3:1 the deliverance from Egypt is mentioned. Keeping in mind that the exodus tradition was an important theological tradition associated with especially the Northern Kingdom of Israel, it is quite possible that mentioning Egypt in Amos 3:9 is also meant as a reminder of the miraculous exodus from Egypt. Mentioning Egypt here is also perfectly in line with the use of the exodus tradition in the two preceding verses where the Exodus from Egypt is mentioned. Israel, who would be well aware of the hardships of oppression by a foreign power, are now oppressing their own people (Snyman 1994:561). What makes it worse is that the foreign power who once acted as the oppressor is now summoned to witness the oppression executed by Israel on its own people. While the fortresses of Egypt and Ashdod will remain safe, the fortresses of Israel will be plundered (Amos 3:11) because the very fortresses mentioned were used to store up the gains gathered by violent means. In other words, the oppressed people were redeemed from oppression only to become oppressors themselves. Recently, Eidevall (2017:132) came to the same solution but added that Ashdod and Egypt were regarded as Israel's archenemies par excellence and that will then be the reason why Ashdod and Egypt in particular were selected.

The mentioning of Ashdod and Egypt brought to mind two prominent traditions. Ashdod recalls the conquest of the land while Egypt served as a reminder of the exodus from Egypt as YHWH's act of salvation par excellence in the history of his people. 


\section{The Exodus turned against Israel}

Amos 4:10

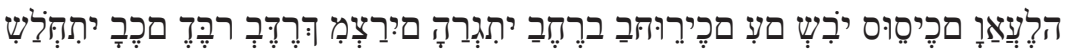

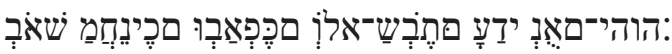

I sent among you a pestilence after the manner of Egypt; I slew your young men with the sword; I carried away your horses; and I made the stench of your camp go up into your nostrils; yet you did not return to me," says the Lord.

Amos 4:10 is part of Amos 4:6-12 which is a prophecy of doom upon Israel and delivered as a "parody of a priestly Torah" (Wolff 1977:211). The prophecy is carefully structured in five strophes (verses $6,7-8 ; 9,10,11$ ) each of them starting with a first person singular verb introducing $\mathrm{YHWH}$ as the one speaking and ending with "Yet you have not returned to me,

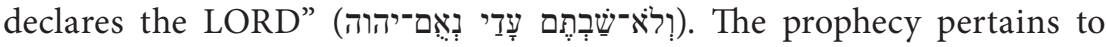
different agricultural catastrophes that will be experienced as a famine (verse 6), a severe drought (verses 7-8), crop failure due to all kinds of pests, a plague or pest (verse 10) and a national disaster of some sort comparable to what happened with Sodom and Gomorrah (verse 11).

The land promised to the people of God will be a good land, a land flowing with milk and honey (Ex 3:8; 17; 13:5; 33:3; Num 13:27; Deut 6:3; 11:9; 26:9; Josh 5:6). It will be a land with abundant pasture for animals to provide milk and an equally abundant of produce to be harvested as a result of the fruitful soil. In Deuteronomy 8:7-10 the land is described as a land with more than enough water and where wheat and barley, vines and fig trees, pomegranates, olive oil and honey will be available where nobody will lack anything. Indeed, during the time of Amos's activity as prophet, Israel experienced a time of peace and prosperity. There was little threat from foreign powers and trade routes passing up and down Transjordan through Israelite territory contributed to a time of economic prosperity. Evidence of this era of economical bloom can be seen from the book of Amos itself. Some Israelites could afford both a summer and winter house (Amos 3:15). Houses were luxuriously furnished and decorated with ivory. Moreover, they could afford it to enjoy the finest quality food available (Amos 6:1-7). 
In Amos 4:10 YHWH says that he sent 'a plague like/according to Egypt'

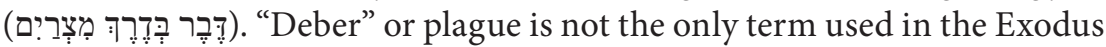
narrative to describe YHWH's actions against pharaoh and the Egyptians. YHWH will act with signs and wonders אות מופת)) and indeed that was the case when the different wonders are described as wonders. The death of the first born is described with another word נגע)). Neither of these terms are used by Amos.

It is a matter of dispute of what is exactly meant by 'a plague like/according to

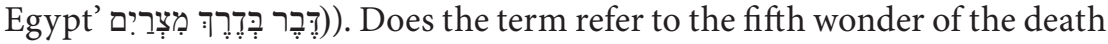
of the livestock of the Egyptians? Or is it possible that this formulation has the tenth plague (the death of the firstborn) in mind? Another possibility is that it is a reference to the plagues in general. Scholarly opinion on this matter gave different answers to the problem of how this phrase has to be understood and at least six possible solutions were proposed.

- Wolff (1977:221) thinks of Exodus 9:3-7 reminding the people of the wonder that killed all the livestock of Egypt.

- Paul (1991:147) opines that the phrase refers to both the disaster that struck the livestock (Ex 9:3-7) as well as the population of Egypt (Ex 9:15).

- Rudolph (1971:179) is convinced that the phrase refers only to the death of the firstborn (Ex 12:29) and not to the fifth wonder.

- A fourth possibility is that 'a plague like/according to Egypt' should be understood as a reference to the plagues in general and not a specific plague as was suggested by other scholars.

- Eideval (2017:147) stated that the "passage alludes to the narrative in its entirety as a long series of calamities (including pestilence) followed by a defeat that wiped out the Egyptian army (Ex 7-15)". Nogalski (2011:303) agrees with this point of view when he states that verse 10 alludes "to the plagues YHWH used against the Egyptians to force Pharaoh to release Israel to Moses" (Ex 7-12).

- Niehaus (1992:401) does not relate this verse with the Exodus events in particular but interprets the verse against a covenantal background referring to Deuteronomy 28:27, 60. 
The fact that Egypt is mentioned specifically serves as an undeniable link

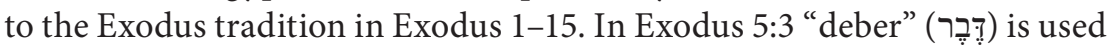
in the speech made by Moses and Aaron to the Pharaoh. In this speech they stated that they wish to offer sacrifices to YHWH "or he may strike us with plagues (דֶָ? or with the sword". It is important to note that "deber" (?ֶ) and the sword are mentioned together here as is the case in Amos 4:10. With the announcement of the death of the livestock of the Egyptians as the fifth plague "deber" (רֶָ? is used again to describe the plague. In Exodus 9:15 "deber" (דָּרֶ) is used to indicate a plague in general when YHWH says: "For by now I could have stretched out my hand and struck you and your people with a plague (דֶָָ t) that would have wiped you off

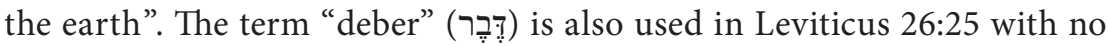
mention of the Exodus but "deber" (רֶָּ) is once again connected to the sword (cf Ex 5:3; Amos 4:10). In Numbers 14:12 the people are threatened with a plague "deber" (דֶָ? that will destroy them. The reason for this action from YHWH is given in the previous verse where YHWH accuses his people they do not believe in him even in spite of all the miraculous signs (האתות) YHWH performed among them. The term "otot" (אתות) is also used to describe the wonders experienced in the plagues that were brought upon Egypt. In Deuteronomy 28:21 the people are threatened with a "deber" (רֶָּ) that will destroy them should they be disobedient in the promised land.

Amos 4:10 is not only linked to the Exodus, it is more specifically linked to the so-called Plague-narrative of Exodus. The term "deber" (רָּ? in Amos 4:10 does not refer to the fifth plague or the death of firstborn but should be interpreted as referring to the total event of the plague-narrative. In the prelude to the signs and wonders to be played out in ten so-called plagues, the plagues and the sword are foreseen in Exodus 5:3. Amos 4:10 recalls the general reference to plagues and the sword as mentioned in Exodus 5:3 rather than a reference to specific plagues.

A powerful contrast is created by the mentioning of the plagues in the Exodus tradition. In the Exodus tradition the plagues were aimed at the Egyptians. Time and again in the plague-narrative it is said that the plagues did not harm the Israelites (Ex 8:22; 9:7; 9:26; 12:12-13). In Amos 4:10 the plagues are directed at the Israelites, the people of God. The people who were once guarded from the devasting effects of the plagues will now suffer 
from plagues. Israel, as the people of God, is punished in the same way as the Egyptians, a foreign nation. In short, the exodus is reversed (Hubbard 1989). Secondly, the plagues were witnessed by the Israelites on foreign soil in Egypt. Now they will experience the plagues in the promised land (Snyman 2006:141). The promised land was supposed to be a land of bounty and fertility. Exactly the opposite will happen now where the people will suffer all kinds of agricultural catastrophes comparable to what happened once in Egypt. Nogalski (2011:303) is right when he observed that YHWH's past actions of salvation are now turned against Israel. Instead of salvation brought about as a result of the plagues, devastation will now be the result of the plagues. In the plague narrative it is repeatedly said that the Pharaoh and the Egyptians had to suffer the plagues brought upon them because of their disobedience to YHWH to let his people go and worship him. Israel will suffer the plagues because they were also disobedient to the voice of God as is implied in the refrain no less than five times in this unit: "you have not returned to me, says the LORD" (Amos 4:6; 8; 9; 10; 11).

\section{The Exodus event not unique to Israel}

Amos 9:7

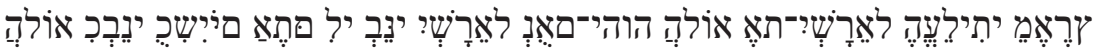

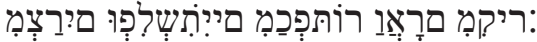

Are you not like the Ethiopians to me, O people of Israel?" says the Lord. "Did I not bring up Israel from the land of Egypt, and the Philistines from Caphtor and the Syrians from Kir?"

Amos 9:7 is part of the second last unit in the book consisting of Amos 9:7-10. Amos 9:7 mentions the exodus of Israel from the land of Egypt. As was noted earlier the only verb (עלה) used in the book of Amos to refer to the Exodus event is used again as was the case in Amos 2:10 and 3:1. YHWH brought his people up from Egypt to the promised land. What is new in this verse is that the Exodus event is put in relief with other similar migrations of other nations. Three different nations are mentioned: the children of Cush, the Philistines, and the Arameans. Mentioning these nations gave rise to the question of why these three nations in particular were mentioned. 
Viewing the text from a literary perspective it is interesting to note that Cush is mentioned first, followed by Israel and then the Philistines and the Arameans are mentioned last. Israel is sandwiched in between the other nations mentioned. The verse displays a "kind of envelope structure" starting with a foreign nation (Cush) and concludes with two other foreign nation nations with Israel at the centre (Strawn 2013:112). Strawn (2013:115) in his thorough poetic analysis of 9:7, concluded that a significant number of poetic devices indicate that the three lines of this verse belong together. The only verb used in this verse (הלע) "stands quite literally at the centre of the unit (Strawn 2013:115) and performs "a triply duty having Israel, the Philistines and Aram as direct objects" (Niehaus 1992:486).

It is also interesting to note that although Cush is not mentioned in the judgement speeches at the beginning of the book, the Philistines are addressed in the second judgement speech in Amos 1:6-8 while the Arameans are addressed in the first judgement speech in Amos 1:3-5. Considering the possibility that Amos 9:11-15 is most likely a later addition to the book, a chiastic structure emerged from the mentioning of the Philistines and Arameans at the end of the book: (A) Arameans (1:3-5); (B) Philistines (1:6-8); (B) Philistines (9:7); (A) Arameans (9:7).

Why Cush is mentioned remains an intriguing question for scholars (Holter 2015:306-318). Smith (1994:36-37) listed no less than ten different answers to this question. Viewing the three nations from a geographical point of view, a universal perspective is created with Israel as the Northern Kingdom, Cush is to be found south of Egypt, Caphtor lies to the west and Kir to the east. YHWH acted on a worldwide scale directing the movement of different nations. YHWH indeed rescued his people from Egypt, but he guided and directed the histories of other nations as well (Smith 1994:47).

The people of Cush were held in high regard during the time of the ministry of Amos. The Cushites were able to subdue the Egyptians during the same time when Amos was a prophet to the Northern Kingdom (Strawn 2013:116121). The Philistines and the Arameans are known as archenemies of Israel (Wolff 1977:347; Van Leeuwen 1985:333).

The Arameans according to 9:7 was once brought from Kir like the Israelites were brought from Egypt. According to Amos 1:5 they will be exiled to Kir. It seems that Aram will be returned by military force to their 
place of origin where they were once brought from by the power of YHWH. Eidevall (2017:236) mentions the possibility that this might be a hint to Israel/Judah that YHWH just might be prepared to reverse the Israelite exodus tradition.

This passage brings together two vital aspects of who God is in the book of Amos. On the one hand there is the firm conviction that the God of Israel is not only a local God served by the Israelites. The God of Israel is also the universal God. This can be seen in Amos 1 and 2 where the moral behaviour of foreign nations does concern YHWH. Social injustices committed by foreign people matter to YHWH. The idea of God as the universal God is expressed again at the end of book in 9:7 where YHWH's action is extended from a local to a universal perspective (Thang 2011:187; Wood 2002:90). On the other hand, it was YHWH who brought his people from Egypt to the promised land. The all-important saving event in the history of God's people is relativized as simply one event amongst other similar events. YHWH delivered his people from Egypt, but he also brought other people to their respective countries. It is noteworthy that the verb used to describe the deliverance of Israel from Egypt is applied to the Philistines and the Arameans as well. It is equally important to note that Amos 9:7 does not say that YHWH entered into a special relationship with the three nations mentioned as is the case in Amos 3:1-2 where it is said that he only knew (ידע) them "of all the families of the earth". In a novel way Amos reinterpreted the Exodus events and applied it to a different situation sometime during the eighth century $\mathrm{BC} / \mathrm{E}$. The way he did it was to relativize this all-important event by comparing the Exodus event with other similar events that happened in the history of other nations in and through YHWH's guidance. What is even more disturbing is the fact that while no judgement is pronounced upon the three nations, Israel, however, is described as "the sinful kingdom" that will be destroyed (Amos 9:8).

\section{The historical context of the book of Amos}

Determining the historical background of a prophetic book is a risky undertaking. Prophetic books have been edited and updated so that it seldom reflects a single historical time. For the purposes of this paper, the historical background reflected in the book is taken as that of the $8^{\text {th }}$ 
century BC/E in Israel, the Northern Kingdom. Eideval (2017:16) confirms this consensus among scholars when he states that "With few exceptions they concentrate on one particular period in the history of the kingdom of Israel, namely the last decades of the reign of Jerobeam II (ca 787-747 BCE)". In Amos 1:1 it is stated that the prophecies in this book were delivered during the time of Jerobeam II, son of Joash, the king of Israel (787/6-747/6 $\mathrm{BC} / \mathrm{E})$. The prophetic activity of the prophet can be dated toward the end of Jerobeam's reign somewhere around $750 \mathrm{BC} / \mathrm{E}$. There was little threat of foreign nations and consequently it was a time of relative peace for both the Northern Kingdom as well as Judah paving the way for economic prosperity (Smith 1994:39-40). Evidence of this time of prosperity could be seen in Amos 3:15 where it is said that some Israelites have both a summer and winter house and that these houses were luxuriously furnished and decorated with ivory where they were feasting on fine quality food (Amos 6:1-7). However, having said this it is also evident that the book was addressed to Judah at a later stage in history. Amos 1:2 states for instance that YHWH roars from Zion (see also Amos 6:1), a tradition more associated with Judah than with Israel. The last part of the book (Amos 9:11-15) speaks of the fallen tent of David that will be restored, once again a tradition that is more at home in a Judean context of exilic and/or even post-exilic times. Recently, Eideval (2017:18-20) suggested no less than six possible historical contexts for the book of Amos.

\section{Conclusion}

The Exodus tradition in the book of Amos is utilized in different ways. The investigation yielded the following results: At first The Exodus from Egypt is used as the motive for the prophecies directed at Israel. YHWH's redemptive actions in the past are put in juxtaposition to the current conditions of the people living in the promised land.

Secondly, the Exodus is turned against Israel. What happened once to the Egyptians will now happen to the people of God. Just as the Egyptians had to suffer plagues, the Israelites will now suffer plagues.

Thirdly, the Exodus event is relativized as an event not unique to Israel. The Exodus is relativized in the sense that the Exodus "was not a unique 
historical-theological event, but rather a divine routine, to transfer nations from one land to another" (Hoffman 1989:181). Barton (2012:72) noted in this regard "precisely because YHWH is a universal God, all the movements of the nations come about through his devising". While it is true that YHWH has caused the exodus, it is also true that "he is responsible for all the movements of peoples on the face of the earth" (Barton 2010:191).

The three ways in which the exodus tradition featured in the book of Amos reveal a "Steigerung": at first the exodus tradition is used as the motivation for the prophecies directed to the people. The second use intensifies the use of the exodus tradition in the sense that the exodus tradition is now turned against Israel while it is in actual fact one of the major redemptive acts of YHWH in the history of Israel/Judah. In the last instance the intensification is even further increased. The exodus was, after all, not the unique event peculiar only to the people of YHWH. In fact, what seemed to be the unique saving event in the history of the people is now relativized by the mentioning of similar events that happened to other people as well.

The book of Amos is well aware of the Exodus tradition. The Exodus tradition is utilized to confirm the major redemptive act of $\mathrm{YHWH}$ in the history of Israel and it is then contrasted to the current situation in the promised land. The book does not only make use of the tradition, it also interprets the tradition and applies it to a new situation. In the plague narrative Egypt was the victim but in the book of Amos the people will suffer the fate previously reserved for the Egyptians. Rather than to view Amos 4:10 as a possible allusion to the exodus "but not indicative of Amos's view on this tradition" (Hoffman 1989:177), it seems better to see the reference to the plagues as an interpretation of the plague narrative and applying it to a new situation. In a similar way, the Exodus that was thought of as a unique event that only happened to Israel, is now put in a broader perspective to reveal the surprising insight that other nations also experienced what may be called exodus events. To claim that the exodus tradition was rejected in the book of Amos (Hoffman 1989:181) is to press the matter a bit too far. It rather seems that the book affirms the exodus tradition so well-known in the Northern Kingdom reminding the people of this famous event and then utilized it in an innovative way to a new era. The deliverance from the land of Egypt contrasted with living in the 
promised land. The familiar event of the miraculous exodus from Egypt gained an unexpected and disturbing message in the book of Amos.

\section{Works consulted}

Barthélemy, D 1992. Critique Textuelle de L' Ancient Testament 3.

Göttingen: Vandenhoeck \& Ruprecht. 647. (OBO 50/3).

Barton, J 2010. The Theology of Amos, in Day, J (ed) Prophecy and Prophets in Ancient Israel. Proceedings of the Oxford Old Testament Seminar. London: T \& T Clark (Library of Hebrew Bible/Old Testament Studies $531)$.

Barton, J 2012. The Theology of the Book of Amos. New York: Cambridge University Press.

Birch, B C; Brueggemann, W; Fretheim, T E \& Petersen, D L 1999. A Theological Introduction to the Old Testament. Nashville: Abingdon

Brueggemann, W 1997. Theology of the Old Testament. Testimony, Dispute, Advocacy. Minneapolis: Fortress.

Carroll, M D 1992. Contexts for Amos: Prophetic Poetics in Latin American Perspective. Sheffield: Sheffield Academic Press (JSOTSup 132).

Deissler, A 1981. Zwölf Propheten. Hosea Joel Amos. Würzburg:Echter Verlag (Neue Echter Bibel).

Eideval, G 2017. Amos. A New Translation with Introduction and

Commentary. New Haven: Yale University Press (Anchor Yale Bible $24 \mathrm{G})$.

Garrett, D A 2008. Amos: a handbook on the Hebrew text. Waco, Texas: Baylor University Press.

Hadjiev, T S 2009. The Composition and Redaction of the book of Amos.

Berlin: Walter de Gruyter (BZAW 393).

Hoffman, Y 1989. A North Israelite Myth and the Judean Historical Tradition: The Exodus in Hosea and Amos. VT 39:169-182. 
Holter, K 2015. Being like the Cushites: Some Western and African Interpretations of Amos 9:7, in Thelle, R I, Stordalen, T \& Richardson, M E J (eds). New Perspectives on Old Testament Prophecy and History. Essays in honour of Hans M. Barstad. Leiden: Brill (SVT 168).

Hubbard, D A 1989. Joel and Amos. An Introduction and Commentary. Nottingham:Inter-Varsity Press. (TOTC).

Jeremias, J 2015. Theologie des Alten Testaments. Göttingen: Vandenhoeck \& Ruprecht (ATD Ergänzungsreihe Band 6).

Mays, J L 1976. Amos: A Commentary. London:SCM (Old Testament Library).

Niehaus, J 1992. Amos, in McComiskey, T E (ed). The Minor Prophets I. Grand Rapids: Baker.

Nogalski, J D 2011. The Book of the Twelve Hosea - Jonah. Macon, Georgia: Smyth \& Helwys Publishing.

Paul, S 1991. Amos. Philadelphia: Fortress. (Hermeneia).

Rendtorff, 2005. The Canonical Hebrew Bible. A Theology of the Old Testament. Leiden: Deo Publishing.

Rudolph, W 1971. Joel - Amos - Obadja - Jona. Güterloh: Gerd Mohn. (KAT XIII/2).

Smith, B K \& Page, F S 1995. Amos Obadiah Jonah. Nashville: Broadman \& Holman Publishers (NAC).

Smith, R 1994. A New perspective on Amos 9:7a: “To Me, o Israel, You Are Just Like the Kushites." Journal of the Interdenominational Theological Center 22:36-47.

Snyman, S D 1994. A Note on Ashdod and Egypt in Amos iii 9. VT 44:559-562.

Snyman, S D 2006. Eretz and Adama in Amos, in Niemann, H M \& Augustin, M (eds). Stimulation from Leiden. Collected communications to the XVIIIth Congress of the International Organization for the Study of the Old Testament, Leiden 2004. Frankfurt am Main: Peter Lang, 137-146. 
Strawn, B A 2013. What is Cush doing in Amos 9:7? The Poetics of Exodus in the Plural. VT 63:99-123.

Thang, R K H 2011. The Theology of the Land in Amos 7-9. PhDdissertation University of Gloucestershire.

Van Leeuwen, C. 1985. Amos. Nijkerk: Callenbach. (De Prediking van het Oude Testament).

Von Rad, G 1975. Old Testament Theology Vol I. London: SCM.

Waltke, B K 2007. An Old Testament Theology - an exegetical, canonical and thematic approach. Grand Rapids: Zondervan.

Wolff, H W 1977. Joel and Amos. Philadelphia: Fortress. (Hermeneia).

Wood, J R 2002. Amos in Song and Book Culture. Sheffield: Sheffield Academic Press (JSOTSup 337).

Zimmerli, W 1978. Old Testament Theology in Outline. Edinburgh: T \& T Clark. 
